\title{
Diseases Patterns Among Adult Hospitalized Patients: A Study Case of BPJS Claim Data in One Hospital in Jakarta
}

\author{
Cicih opitasari ${ }^{1, *}$, Nurhayati $^{1}$ \\ ${ }^{1}$ Center for research and development of health resources and services, National Institute of Health Research and \\ Development, Jakarta, Indonesia \\ *Corresponding Author.Email: vitasari2010@gmail.com
}

\begin{abstract}
Disease patterns are important to provide an overview of the health situation. It could be used to formulate health policy, improve quality of health care or set the appropriate budget allocations. Objective: This study aims to analyze the pattern of the disease in adult hospitalized BPJS patients. Method: This cross-sectional study was carried out in one type A hospital in Jakarta. All claim data of BPJS inpatients who admitted during the period of January to December 2017 were included in the analysis, among those with age less than 18 years old were excluded. The data were analyzed descriptively. Results: There were 15,258 adult BPJS inpatients, of which 3,578 (2,3\%) were readmission resulting for 18,836 admission throughout 1 year. The female patients $(57,70 \%)$ were higher than males $(42,30 \%)$, with an average of age was $49 \pm 16$ years and mean length of hospital stay was $9 \pm 8$ days. Cardiovascular system groups were the leading cause of admission, however the respiratory system groups was the commonest diseases causing long hospitalization, the major cause of death and spending the largest of INA-CBG's claim. The overall mortality rate among adult BPJS inpatients was 14.6\%. Conclusion: Non communicable diseases appear to be the most prominent sources of morbidity, mortality and hospitalization cost among adult hospitalized BPJS patients.
\end{abstract}

Keywords: diseases, pattern, adult BPJS inpatient

\section{INTRODUCTION}

Disease patterns are important to provide an overview of the health situation. It could be used to formulate of health policies or determine policy priorities, improve quality of health care, maintaining equity or set the appropriate budget allocations.[1] [2] Globally, the epidemiological transition from communicable diseases to non-communicable diseases is increasingly apparent in 2030. Morbidity due to noncommunicable diseases and injuries is projected to rise while communicable diseases will decline.[3] In terms of mortality, the total number of non-communicable diseases death is twice that of the combined total of all infectious diseases (including HIV/AIDS, tuberculosis and malaria), maternal and perinatal conditions and nutritional deficiencies.[4] Most noncommunicable diseases is associated with an increase in risk factors due to four particular lifestyle changes : tobacco use, physical inactivity, unhealthy diet and the harmful use of alcohol.[3] Indonesia is afflicted with a triple burden of diseases in the last few decades. In respect with communicable diseases, there are still a problem with the frequent outbreaks of certain infectious diseases, reemerging diseases and new emerging diseases such as HIV / AIDS, Avian Influenza, Swine Flu and Nipah Diseases. On the other hand, non-communicable diseases continue to increase over time.[5] Government has launched the National Health Insurance system (Jaminan Kesehatan Nasional hereafter referred to as JKN) in early 2014 managed by the Social Security Administrative Body (Badan Penyelenggara Jaminan Sosial / BPJS Kesehatan). The program has the positive impact to increase access to health services including hospitals.[6] This study aims to analyze the pattern of the disease in adult hospitalized BPJS patients.

\section{METHOD}

This cross-sectional study was carried out in one type a hospital which is one of the national referral hospital in Jakarta. The samples were selected by using purposive sampling technique. All claim data of BPJS inpatients who admitted during the period of January to December 2017 were included in the analysis, among those with age less than 18 years old were excluded.

The data collected were: age, sex, length of hospital stay, diseases groups, number of admission, number of patients, number of inpatient hospital death, mortality rate and INACBG tariff. Age was presented as a mean $\pm \mathrm{SD}$ as well as was grouped into seven categories: 18-25, 26-30, 31-40, 41-50, $51-60,61-70$ and $\geq 71$ years old. Sex was divided into 


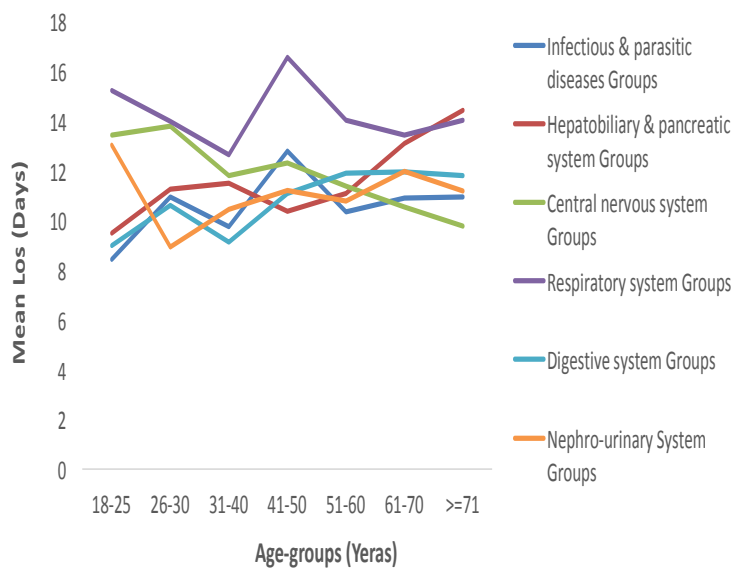

two categories: male and female, length of hospital stay was presented as a mean \pm SD as well as was categorized into six groups: $0-9,10-18,19-27,28-36,37-45$ and $\geq 46$ days. The disease group presentations were based on the 29 Casemix Main Groups in INA-CBG. Mortality rate was defined as the number of hospital inpatient death divided by the total number of patients.

The data were analyzed descriptively using SPSS for Windows version 16. Ethical approval was obtained from Ethics Committee, Faculty of Public Health, University of Indonesia with letter number: 564/UN2.F10/PPM.00.02/2017.

\section{RESULTS AND DISCUSSION}

There were 15,258 adult BPJS patients admitted to the ward in hospital X throughout 1 year, of which 3,578 (2,3\%) were readmission hospitalizations. In total, the number of admission were 18,836 times for 1 year. Table 1 presents the characteristics of adult hospitalized BPJS patients consist of $42,30 \%$ males and $57,70 \%$ females (female to male ratio:1,36), with an average of age was $49 \pm 16$ years and overall, the mean length of hospital stay was $9 \pm 8$ days.

The six top CMGs cause long hospitalization have been showed in figure 1 among others infectious and parasitic diseases, hepatobilliary and pancreatic disease, central nervous system, respiratory disease, digestive disease groups and nephro-urinary diseases groups. The most common diseases lead long hospitalization was the respiratory disease groups ( $14 \pm 11$ days) which happen in all ages and reach its peak at 41-50 years old.

Similarly, the infectious and parasitic diseases groups also

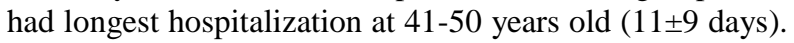
Mean LoS of central nervous and nephro-urinary system groups ((11 \pm 9 days) had increased at younger adult while hapatobilliary-pancreatic (12 \pm 9 days) and digestive system groups (11 \pm 9 days) increased in elderly patients.

Table 1. The Characteristics of Adult Hospitalized BPJS Patients

\begin{tabular}{lcccc}
\hline \multicolumn{1}{c}{ Variables } & $\begin{array}{c}\text { Frequency } \\
(\mathrm{N}=15.258)\end{array}$ & $\begin{array}{c}\text { Percentage } \\
(\%)\end{array}$ & Mean & SD \\
\hline Sex & & & & \\
Male & 6457 & 42.30 & & \\
Female & 8801 & 57.70 & & \\
& & & & \\
Age (Years) & & & & \\
$18-25$ & 1469 & 9.60 & & \\
$26-30$ & 1022 & 6.70 & & \\
$31-40$ & 2497 & 16.40 & & \\
$41-50$ & 2889 & 18.90 & 49 & 16 \\
$51-60$ & 3443 & 22.60 & & \\
$61-70$ & 2481 & 16.30 & & \\
$>=71$ & 1457 & 9.50 & & \\
& & & & \\
Length of stay & & & & \\
(days) & & & \\
$0-9$ & 10379 & 68.00 & 9 & 8 \\
$10-18$ & 3362 & 22.00 & & \\
$19-27$ & 951 & 6.20 & & \\
$28-36$ & 340 & 2.20 & & \\
$37-45$ & 121 & 0.80 & & \\
$>=46$ & 105 & 0.70 & & \\
\hline
\end{tabular}

Figure 1. Case-mix main groups cause long hospitalization

Table 2 illustrates that cardiovascular system groups is the leading cause of admission, accounting for $13,1 \%$. The overall mortality rate among adult BPJS inpatients was $14,6 \%$, which the respiratory system groups was the major disease groups causing the highest mortality in hospital, followed by infectious and parasitic disease groups as much as $41,2 \%$ and $40,4 \%$ respectively.

Table 2. Number of Admission, Patients, Inpatient Hospital Death and Mortality Rate by Case-Mix Main Groups

\begin{tabular}{|c|c|c|c|c|c|c|c|}
\hline \multirow[t]{2}{*}{ Case-mix Main Groups } & \multicolumn{2}{|c|}{$\begin{array}{l}\text { Number of } \\
\text { Admission }\end{array}$} & \multicolumn{2}{|c|}{$\begin{array}{c}\text { Number of } \\
\text { Patients }\end{array}$} & \multicolumn{2}{|c|}{$\begin{array}{c}\begin{array}{c}\text { Number of } \\
\text { inpatient hospital } \\
\text { death }\end{array} \\
\end{array}$} & \multirow{2}{*}{$\begin{array}{c}\begin{array}{c}\text { Mortality } \\
\text { rate }\end{array} \\
\%\end{array}$} \\
\hline & $\mathrm{n}$ & $\%$ & $\mathrm{n}$ & $\%$ & n & $\%$ & \\
\hline Cardiovascular system Groups & 2561 & 13.6 & 2005 & 13.1 & 322 & 14.4 & 16.1 \\
\hline $\begin{array}{l}\text { Factors influencing health status \& other } \\
\text { contacts with health services Groups }\end{array}$ & 1821 & 9.7 & 1540 & 10.1 & 387 & 17.3 & 25.1 \\
\hline Central nervous system Groups & 1688 & 9.0 & 1459 & 9.6 & 350 & 15.7 & 24.0 \\
\hline $\begin{array}{l}\text { Musculoskeletal system \& connective } \\
\text { tissue Groups }\end{array}$ & 1588 & 8.4 & 1394 & 9.1 & 43 & 1.9 & 3.1 \\
\hline Nephro-urinary Yystem Groups & 1568 & 8.3 & 1051 & 6.9 & 181 & 8.1 & 17.2 \\
\hline Female reproductive system Groups & 1498 & 8.0 & 1193 & 7.8 & 23 & 1.0 & 1.9 \\
\hline Digestive system Groups & 1448 & 7.7 & 1127 & 7.4 & 116 & 5.2 & 10.3 \\
\hline Deliveries Groups & 1353 & 7.2 & 1290 & 8.5 & 0 & .0 & 0.0 \\
\hline Respiratory ysytem Groups & 1326 & 7.0 & 1137 & 7.5 & 468 & 20.9 & 41.2 \\
\hline $\begin{array}{l}\text { Myeloproliferative system \& neoplasms } \\
\text { Groups }\end{array}$ & 640 & 3.4 & 294 & 1.9 & 17 & 8 & 5.8 \\
\hline $\begin{array}{l}\text { Heppatobiliary \& pancreatic system } \\
\text { Groups }\end{array}$ & 609 & 3.2 & 515 & 3.4 & 74 & 3.3 & 14.4 \\
\hline $\begin{array}{l}\text { Skin, subcutaneous sisule \& breast } \\
\text { Groups }\end{array}$ & 606 & 3.2 & 484 & 3.2 & 27 & 1.2 & 5.6 \\
\hline $\begin{array}{l}\text { Endocrine system, nutrition \& } \\
\text { metabolism Groups }\end{array}$ & 557 & 3.0 & 452 & 3.0 & 52 & 2.3 & 11.5 \\
\hline Ear, nose, mouth \& throat Groups & 549 & 2.9 & 481 & 3.2 & 8 & 4 & 1.7 \\
\hline Infectious \& & 354 & 1.9 & 314 & 2.1 & 127 & 5.7 & 40.4 \\
\hline Hamopopoitic \& immune sy & 336 & 1.8 & 218 & 1.4 & 28 & 1.3 & 12.8 \\
\hline Male reproductive System Groups & 141 & 0.7 & 122 & 0.8 & 1 & 0.0 & 0.8 \\
\hline Eye and Adnexa Groups & 116 & 0.6 & 108 & 0.7 & 0 & 0.0 & 0.0 \\
\hline $\begin{array}{l}\text { Injuries, poisonings \& t toxic effects of } \\
\text { drugs Groups }\end{array}$ & 69 & 0.4 & 68 & 0.4 & 6 & 0.3 & 8.8 \\
\hline Menalal Heallh and Behavioral Groups & 8 & 0.0 & 6 & 0.0 & 4 & 0.2 & 66.7 \\
\hline otal & 18.836 & & 15.25 & & 2234 & & \\
\hline
\end{tabular}

Figure 2 shows the mean, maximum and minimum of INACBGs tariff based on Case-mix Main Groups. It appears that the average as well as the maximum tariff of INACBGs for the respiratory disease group is the largest compared to other groups of diseases that is equal to approximately Rp. 31 millions of average tariff and reach up to approximately 208 million rupiah for the maximum tariff. Furthermore the musculoskeletal disease system groups ranks the second largest in average and maximum tariff of INA-CBGs. 
The limitation of this study was only conducted in one hospital, hence the findings cannot be generalized to the entire hospital in Indonesia. But it provides useful information on the disease patterns of adult hospitalized patients in type A hospital as a national referral hospital.

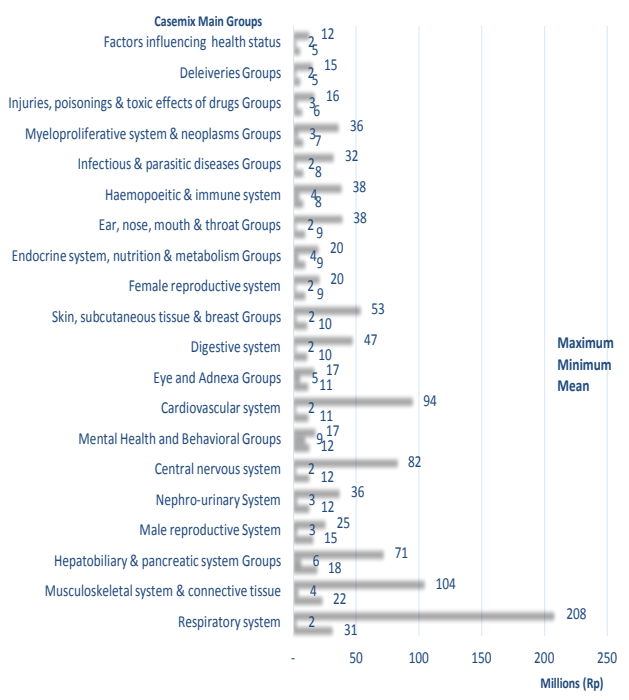

Figure 2. INA-CBGs tariff per Case-mix Main Groups

This study found that female to male ratio was 1,36 suggesting that females were more likely to be hospitalized compared with males. Similiarly, Anunnatsiri et al reported the female to male ratio in Thai adult hospitalized patients was 1.36.(1) Other study by Abaerei in South Africa also mentioned that females were approximately twice as likely to seek health-care compared to males [7]. In Pakistan, males were more dominant in determining the health needs. Females were usually not permitted to visit a health facility or to make decision for health care cost [8]. In addition to empowerment of women, the existence of JKN program ensure health services in hospitals that are accessible without resulting in lost income.

The respiratory disease groups was the commonest diseases groups cause long hospitalization and highest mortality. Respiratory diseases impose an enormous global health burden.[9] The clinical variables at the time of admission were associated with the prolong of length hospital stays, among others high Pco2 levels, symptoms that were present for more than 1 day, and antibiotic treatment [10]. The respiratory disease was among the leading causes of NCD deaths worldwide (after cardiovascular diseases and cancer). Almost $90 \%$ of deaths from chronic obstructive pulmonary disease, occur in low- and middle-income countries [3][11].

The hapatobilliary-pancreatic diseases groups were the second greatest lead longer hospital stay and mainly in elderly patients. As the population ages, the frequency of idiopathic and autoimmune pancreatitis increased and the onset of autoimmune occurred at $>60$ years old in most cases.[12] Major hepatobiliary-pancreatitic diseases were treated with surgery. However, the risk of postoperative complication increased with advanced age due to high comorbidity in elderly patients.[13]

The leading cause of admission was cardiovascular system groups accounted for $13.1 \%$. In contrast, Anunnatsiri et al in Thailand revealed certain infectious and parasictic diseases were the most prevalent of hospital admission among adult patients under national health insurance system in 2010.[1] The different result, probably due to the difference study time is relatively long with this study. Meanwhile more recent study by Al-Ghamdi reported similar finding that cardiovascular diseases were considered the leading cause of hospital admission in a teaching community hospital in Saudi Arabia [14].

The mean and the maximum tariff of INA-CBGs for the respiratory disease group is the largest compared to other groups of diseases, accounted for Rp. 31 million and 208 million rupiah respectively. Respiratory diseases were also as the most frequent diseases with long hospitalization which may contribute for increasing hospitalization cost. This was in accordance with previous study that length of stay was significantly associated with hospitalization cost for respiratory diseases, particularly for chronic obstructive pulmonary diseases [15][16].

\section{CONCLUSION}

Non communicable diseases seem to be the most prominent sources of morbidity and mortality among adult hospitalized BPJS patients. Government should strengthen the primary care physicians to prevent and manage chronic illnesses adequately at the primary level.

\section{REFERENCES}

[1] Anunnatsiri S, Reungjui S, Thavornpitak Y, Pukdeesamai P, Mairiang P. Disease Patterns among Thai Adult Population: An Analysis of Data from the Hospitalization National Health Insurance System 2010. J Med Assoc Thai. 2012;95:74-80.

[2] Onoh C, Aguocha J, Osuagwu IK, Amadi CO, Akalonu GI, Nwabueze RN. Magnitude and Pattern of Disease Presentation among Students in Federal University of Technology Owerri Nigeria. IOSR J Dent Med Sci. 2017;16(3):116-21.

[3] WHO. Global status report on noncommunicable diseases. 2010.

[4] Mokdad AH. Global non - communicable disease prevention : Building on success by addressing an emerging health need in developing countries. J Heal Spec. 2016;4(2):92-104.

[5] kementerian kesehatan RI. Penyakit tidak menular. Vol. 2, Buletin jendela data dan informasi kesehatan. 2012.

[6] Irwandy, Sjaaf AC. Dampak Kebijakan Jaminan Kesehatan Nasional terhadap Efisiensi Rumah Sakit: Studi Kasus di Provinsi Sulawesi Selatan 
The Effect of Health Insurance National Reform on Hospital Efficiency. J MKMI. 2018;14(4):360-7.

[7] Abaerei AA, Ncayiyana J, Levin J. Health-care utilization and associated factors in Gauteng province, South Africa. Glob Health Action [Internet]. 2017;10(1):1-9. Available from: https://doi.org/10.1080/16549716.2017.1305765

[8] Shaikh BT, Hatcher J. Health seeking behaviour and health service utilization in Pakistan: challenging the policy makers. J Public Health (Bangkok). 2004;27(1):49-54.

[9] Forum of International Respiratory Societies. The Global Impact of Respiratory Disease. 2017.

[10] Mushlin A, Black E, Connolly C, Buonaccorso K, EBerly S. The Necessary Length of Hospital Stay for Chronic Pulmonary Disease. JAMA. 2019;266(1):80-3.

[11] European Respiratory Society. The burden of lung disease. In 2010. p. 2-15. Available from: https://www.erswhitebook.org/files/public/Chapt ers/01_burden.pdf

[12] Kamisawa T, Yoshiike M, Egawa N, Nakajima H, Tsuruta K, Okamoto A, et al. Chronic Pancreatitis in the Elderly in Japan. Heal Med Collect. 2004;4:223-8.

[13] Kim JH, Min SK, Lee H, Hong G, Lee HK. The safety and risk factors of major hepatobiliary pancreatic surgery in patients older than 80 years. Ann Surg Treat Res. 2016;91(6):288-94.

[14] Al-ghamdi MA, Abdulhak AA Bin. Pattern , duration of stay, and outcomes of medical admissions : a report from teaching community hospital in Assir region, Saudi Arabia. J Community Hosp Intern Med Perspect [Internet]. 2018;8(2):53-6. Available from: https://doi.org/10.1080/20009666.2018.1454789

[15] Li M, Wang F, Chen R, Yang Y, Chen S, Oi C, et al. Factors contributing to hospitalization costs for patients with COPD in China: a retrospective analysis of medical record data. Int J Chron Obs Pulmon Dis. 2018;13:3349-57.

[16] Torabipour A, Hakim A, Angali KA, Dolatshah M, Yusofzadeh M. Cost Analysis of Hospitalized Patients with Chronic Obstructive Pulmonary Disease: A State-Level Cross- Sectional Study. Tanaffos. 2016;15(2):75-82. 